\title{
Constructivism and the Likert Scale on the Perception of Teaching/Learning Creativity at the University Level
}

\author{
Ng'ang'a, S.I. (PhD) \\ Senior Lecturer and Dean, School of Business, Karatina University College, Kenya \\ Otii, L.O. \\ County co-operative officer, Kericho County
}

Accepted: December 17, 2012 Published: January 26, 2013

Doi:10.5296/jsr.v4i1.3159 URL: http://dx.doi.org/10.5296/jsr.v4i1.3159

\begin{abstract}
This paper interrogates the constructivists learning environment, the constructivists learning activities and the use of the likert scale in assessing the effectiveness of teaching/learning creativity at the university level. The rapid growth in demand of university education, the rapid expansion and proliferation of both public and private universities and university colleges and the privately sponsored student programs necessitates that we continuously monitor and evaluate their performance and the creative abilities bestowed upon graduates as they join the labor market. The paper is informed by a case of a postgraduate student who sought to investigate and analyze from the students perspective, the input factors into a university system through a transformation process that leads to graduates who are expected to have creative capabilities and fit into the ever changing society. The thesis examination process was faced by challenges that lead to the program taking six years instead of the prescribed two, yet he is still the lucky one, the most of his class mates are not that lucky. The authors relate the experience they shared as student and supervisor in the process. The paper concludes that there is a problem in the constructivist learning environment created-the faculty, facilities and programs and also dissatisfaction in the methodologies employed and the role played by the facilitators. It is therefore recommended that the universities should re-examine the environment, the transformation process and the outputs to ensure that graduates meet the dynamic needs of a global society.
\end{abstract}

Keywords: Constructivism, likert scale, Teaching/Learning creativity and innovation, faulty, teaching methods and constructivists leaning environment

\section{Introduction}

Creativity, which is a mental and social process involving discovery of new ideas, concepts or 
new associations of the creative mind, is crucial for innovation. Innovation and entrepreneurship are important in business because creative business build competitive advantage that enables them survive and grow in a globalized economy. University graduates who become employees and eventually managers of enterprises and business firms are expected to have creative abilities which they can exploit when called upon to do so in the working life and therefore cause change in the work environment. Sternberg (1999) notes that, creativity is fuelled by the process of either conscious or unconscious insight and that the product of a creative mind and divergent thought has both originality and appropriateness. Universities are expected to create an environment and facilitate learning of creativity. Wellestarnd and Tjedoll (2003) observed that school leavers and university graduates who can think critically and respond creatively will more likely be able to meet the challenges of the $21^{\text {st }}$ century by contributing positively to the personal, social, technological and economic world that they will eventually inhabit.

The challenge in institutions of higher learning and universities in Least Developed Countries is in creating such a learning environment, attracting and retaining faculty and other communities with social environment that is open to creativity and diversity of many kinds as noted by Donald and Marrow (2003). The other challenge is that of assessing, measuring and ensuring that the graduates entering the labor markets have acquired the pre-requisite creative abilities.

\section{The Problem Statement}

Constructivism can and has been used to explain society's perception by the fact that a particular society can build the same "constructs" based on past experience or environment that they have been through. Based on this social perception, universities are expected to provide a constructivists learning environment (CLE) where the learning goals may include issues or questions, case studies, long term projects and/or problem solving and the facilitators (faculty) play the role of modeling, coaching and scaffolding (Joassen, 1999). The problem is whether such environment is created and whether the faculty plays their role in facilitating learning of creativity. The ultimate challenge is how the actual results, final product (the graduate) is ascertained to possess the actual creative abilities. Would the likert scale be an appropriate tool for measuring creative abilities acquired by graduates assuming that the university has provided a constructivists learning environment?

\section{The Purpose of the Paper}

The purpose of this paper is to interrogate the use of the constructivism and the likert scale in assessing creativity among graduating undergraduate students by postgraduate students in a selected university in Kenya. This will bring out issues specific to the university versus the creative learning environment touching on student's aptitude, faculty competence, Programs, facilities, and methods. 


\section{Literature Review and Conceptual Framework}

Creativity has been studied from the perspective of behavioral psychology, social psychology, psychodynamics, cognitive sciences, artificial intelligence, philosophy, aesthetics, history, economics, design, research, business and management among others to underscore its importance (Sternbberg, 1999). Creativity leads to innovation while innovation and entrepreneurship enables business compete in global market. Products availed in a market must have been ideas before commercialization and the same can be said of the production processes before implementation. This suggests that availability of highly skilled workers in a region is determines the success and dynamism of locally based enterprises, clusters and regional innovative systems. The role of the university is to facilitate the direct and indirect transfer of technology and flow of knowledge through producing well educated talent for the local and national labor market. Donald and Marrow (2003 notes that the university through its graduate programs, has a crucial role to play in facilitating global flow of knowledge which it achieves through the ability to attract creative people and to be open to diverse groups of people of different ethnic, racial and life style groups that provides distinct advantage to regions in generating innovations, growing and attracting competitive industries and clusters and spurring economic growth. The universities create a social environment that opens dialogue and debate, tolerant of different viewpoints and accessible to many different social, ethnic and cultural groups (Local, national and international) hence universities are expected to remove and/or minimize barriers to entry and work towards social inclusion. The universities are also expected to act as a magnet by making places attractive to highly skilled research talents - Research, collaborations, ability to learn from peers, linkages and cross discipline learning that make them attractive for developing creativity (Storper and Venables, 2004). Finally, universities should attract both firms and talent (student and faculty) where strong research-intensive universities with graduate programs also tend to have strong undergraduate teaching programs that attract domestic and foreign students alike. When universities facilitate leaning of creativity, the participants feel fulfilled. Csikszentmihalyi (1996) observed that when we are engaged in creativity we feel that we are living more fully than during the rest of the life and that as well as the excitement of the involvement, being creative leaves a product/effect that adds to the intensity and complexity of future life.

\section{Constructivism and creativity}

Constructivism is a theory of learning and an approach to education which lays emphasis on the methods that people use to create a meaning of the world through a series of individual constructs (Glaserfeld, 1996). Constructivism is used to impart learning to a particular student or group of students by allowing a student first experience a particular environment or experience firsthand or on their own which in turn will give them trustworthy and reliable know how about how to tackle the same particular environment or experience in the future (Glaserfeld, 1996). The constructivism focus on social nature of cognition gives learners the opportunity for concrete, contextually meaning experience through which they can search for patterns, raise their own questions and construct their own models; facilitate a community of 
learners to engage in activity, discourse and reflection and encourage students to take on ownership of the ideas and move to pursue autonomy, mutual reciprocity of social relations and empowerment to pursue the goals (Brunner, 1986). Brunner (1986) further notes that the implication of the constructivism approach to learning is learning in an authentic context where the conception of mediation gives the emphasis to interaction between individuals and the historical and cultural development and also provides scaffolding where learning takes place in the social interaction with older, more learned members of society. The International Society of for Technology in Education (ISTE) (2007), provide educators with a blue print for designing educational and technological experiences to equip students to thrive in the modern, connected world. The categories of skills emphasized include creativity and innovation, communication and collaboration, research and information fluency, critical thinking, problem solving and decision making, digital citizenship and technology operations and concepts (ISTE, 2007).

The constructivist learning environment (CLEs) may include goals such as questions or issues, case studies, long term projects or problems that involve multiple cases and projects integrated at the curriculum level (Laffey et al, 1997). When undergraduate and graduate students undertake projects, several constructivists learning activities may or are involved that may include experimentation, research on topics and presentations, field activities or trips, films or role play as well as classroom discussions. During such activities the facilitators play the role of modeling, coaching or scaffolding (Laffey et al, 1997). In modeling, two types are discernable; behavioral modeling where the overt performance demonstrates how to perform the activities identified in the activity structure while in cognitive modeling the covert cognitive process articulates reasoning (reflection in action) that the learner should use when engaged in the activities. In coaching the facilitator motivates learners, analyses performance, provides feedback and advice on the performance on how to learn about how to perform and provokes reflection and articulation of what is learned. In scaffolding, the facilitator provides a more systematic approach to supporting the learner, focusing on the task, the environment, the teacher and the learner. Scaffolding provides temporary frameworks to support learning and students performance beyond their capacities (Laffey et al, 1997).

When students engage in projects, constructivism occurs beyond the individual through multiple forms and levels of thinking. According to Fauconnier and Turner (2002), both individual group processes are the means by which new knowledge is created. In knowledge management, perspectives on different types of knowledge for example, tacit and explicit, introduce classification of thinking into creative and problem solving both of which occur in projects. In projects, rational thinking includes mainly problem solving, planning and other pre-meditated forms of cognitive processes. The forms of cognition thinking include insight, inspiration, cognitive leaps, analogy, metaphor and triggers for illumination (Faconnier and Turner, 2002). Consequently, the ideal classroom for constructivists teaching should have characteristics that include among others learner involvement, democratic environment, student centered and interactive activities and teacher facilitation that allow students to be 
responsible and autonomous.

\section{Assessment and measurement of constructivists learning and creativity}

Measuring of teaching creativity's effectiveness is important since it gives evidence necessary for making decisions about the future in academic development and instructions contributions in the labor market of skills required for economic development. The decisions may require evidence of measurements to improve and shape the quality of teaching or determine the overall performance that may inform annual merit related pay, promotion or tenure of faculty members. Individual creativity has been measured in a number of different ways, ranging from the assessment of the characteristics and personality traits of highly creative individuals to the measurement of creative products and achievements. In constructivists teaching, assessment is based on tasks, observation of the student, the students work and also the students view points. Laffey et al (1997) suggest that the assessment strategies may include oral presentations where students are allowed to discuss a focus question, the KWLH chart that involve what we Know, what we Want to know, what we have Learned and How we know it, Mind mapping where students list and categorize concepts and ideas relating to a topic, hands on activities that encourage students to manipulate their environment or a particular learning tool and pre-testing that allows teachers to determine what knowledge students bring into a new topic and thus will be helpful in directly the course of study. Seldin (1999) indicates that there are twelve potential sources of evidence of effectiveness which include students ratings, peer ratings, self-evaluation, videos, student interviews, alumni ratings, employer ratings, administrator ratings, teaching scholarships, teaching awards, learning outcomes measures and teaching portfolio. In assessing creativity, Baer (2008) concluded that creativity is best conceptualized as domain specific and argued that this domain specificity explains why divergent-thinking tests have not met with more success. Mumford et al (2008) also questioned the validity of divergent-thinking tests. However, other researchers have defended divergent-thinking measures, such as those used in the Wallach-Kogan Creativity Tests (Cheung et al. 2004, Lee 2008). A host of other researchers and psychometricians have been busy with the close examination of existing creative-ability and creative personality measures and the development of new ones (Epstein et al. 2008, Nassif \& Quevillon 2008, Silvia et al. 2008). In short, some of the possible solutions in measuring creativity include the use of expert raters (Amabile, 1996), divergent thinking based scoring of creative products for originality or fluency (Reiter-Palmon et al, 2009), or assessment of a product's historical impact (Simonton, 2009). Horn and Salvendy (2006) offer a detailed comparison of specific product creativity measurement tools, including likert scale and subjective assessments.

The Likert scale was developed by Rensis Likert in 1932 for measuring attitudes by asking people to respond to a series of statements about a topic, in terms of the extent to which they agree with them, and so tapping into the cognitive and affective components of behavior (Likert, 1932). Likert-type or frequency scales use fixed choice response formats and are designed to measure attitudes or opinion (Bowling, 1997; Burns and Grove, 1997). These 
ordinal scales measure levels of agreement or disagreement. A lickert scale assumes that the strength/intensity of experience is linear, that is, on a continuum from strongly agree to strongly disagree. A respondent may be offered a choice of five (5), seven (7), nine (9) or even more pre-coded responses with the neutral point being neither agree nor disagree. The tool has the advantage in that it is able to obtain data on attitude, perception or opinion in degrees of opinion/perception levels and hence quantitative data that make analysis easy. Critics of the tool have argued that validity may be compromised due to social desirability hence bias. This has been countered by recommending anonymity during administration of the instrument (McLeod, 2008). In analyzing and reporting Likert scale data, the sum of the values of each response is aggregated to create a score for each respondent on each question that represents a particular trait when used in a sociological or psychological research. The data is then used to create a chart for distribution of opinion a cross the population computes medians, mode and or carry out cross tabulations of the mean with contributing/causative factors. Regression and correlation analysis has been used in testing the relationships between the factors of interests (Alfa et al, 2007; Kalyar, ---). The question of 5 or 7 point Likert scale has been debated and is a main cause of concern in this paper. It has been argued that the 7 point scale is not used or confuses the respondent. Dawes (2008) conducted an experiment on the 5, 7 and 10 point scales and concluded that the 5 and 7 point scales produce the same mean score as each other once they are rescaled. One strong point in arguing in favor of the 7 point scale is the spread in the fixed choice and hence fairly well differentiated scores between respondents that give the research confidence as he progresses with data scoring, coding and analysis otherwise the results would be basically the same. A typical example of a seven point Likert scale with clear and distinct boundaries may seek to level of satisfaction and read as follows completely dissatisfied (1); mostly dissatisfied (2); somewhat dissatisfied (3); neither satisfied nor dissatisfied (4); somewhat satisfied (5); mostly satisfied (6) and completely satisfied (7). On frequency of say, use of an item/technology or method the points could be demarcated as follows never (1); rarely (2) use being less than $10 \%$ of the chances that one may have; occasionally (3) less than $30 \%$ of the chances that may arise; sometimes (4) $50 \%$ of the chances; frequently (5) about $70 \%$ of the chances; usually (6) about $90 \%$ of the chances that one could have and every time (7). Essentially creativity is also called to play a role in the design of the likert scale.

Alfa* (the post graduate student) conceptualized the teaching and learning at the university level as a simple production function. It was pointed out a production function is a description of the technological conditions of production that combines inputs to produce outputs. The study considered a simple production process: inputs into the university as a productive unit where they undergo a transformation process to yield outputs (graduates) with desired characteristics and qualities to address society's needs as illustrated in figure 1. 


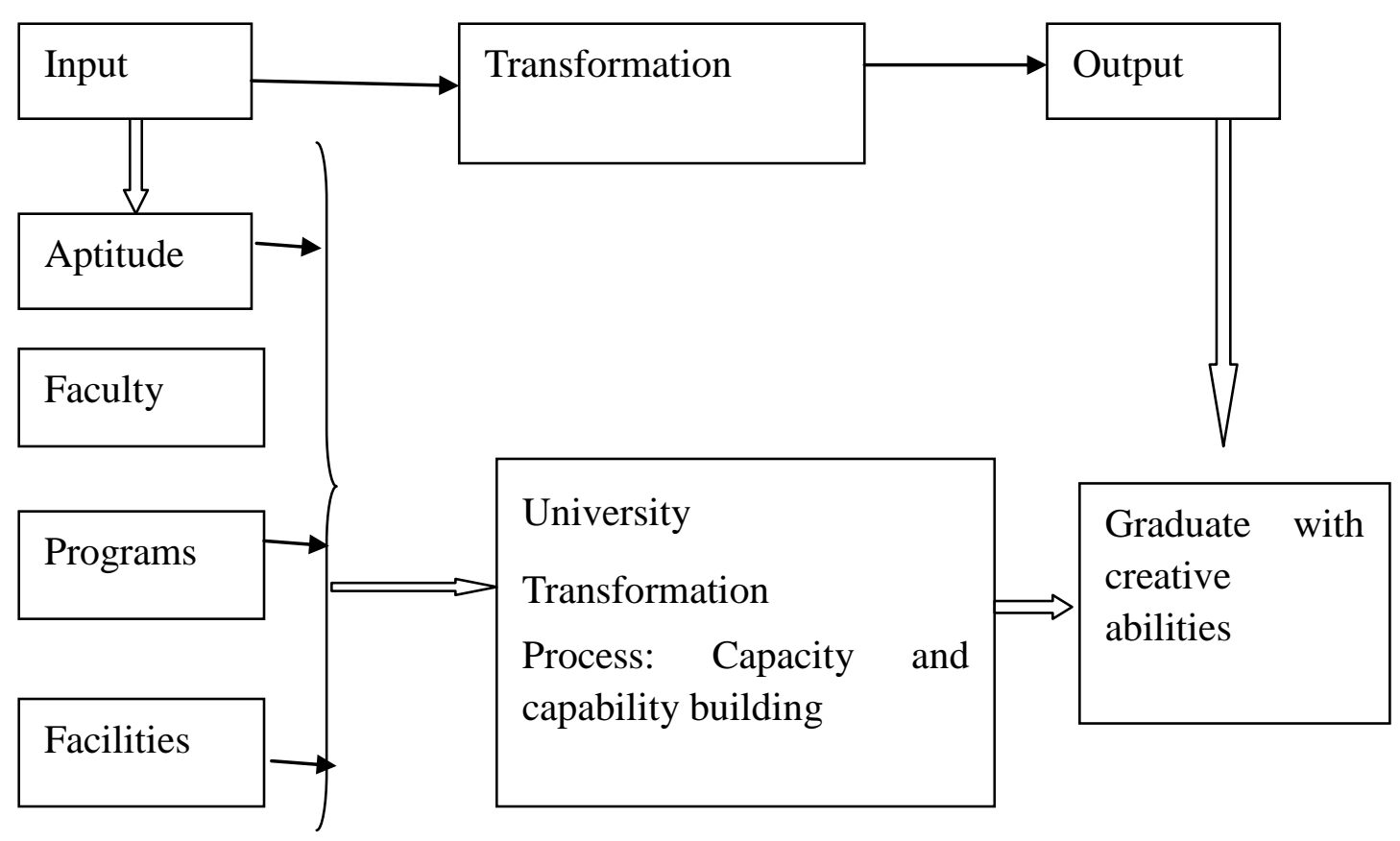

\section{Methods}

Figure 1: The productive process in an institution of higher learning

Source: Alfa et al (2011)

Note: Alfa* is a pseudo name adopted to conceal the true identity of the postgraduate student for confidentiality purposes.

In a constructivist learning environment the same model can be reconstructed into inputs, transformation and output as shown in figure 2.

Constructivists Learning Environment
(Inputs)
Communities
-Students of high aptitude (Local and
Foreign)
-Highly skilled workers
-High caliber faculty and researchers
-Diverse groups of people- Different
ethnic, racial, lifestyles,
culture, religion and regional
background.
-Collaborators, industry and
community linkages
Programs
-Research intensive graduate
programs
- Attractive undergraduate programs

\begin{tabular}{|c|c|}
$\begin{array}{c}\text { Constructivists Learning Activities } \\
\text { (Transformation) } \\
\text {-Teaching methods that } \\
\text { emphasize interactive and } \\
\text { experiential learning } \\
\text {-Facilitation that involve } \\
\text { modeling, coaching and } \\
\text { scaffolding } \\
\text {-Learning goals that include }\end{array}$ & $\begin{array}{c}\text { Learning Effectiveness and creativity } \\
\text { (Output) } \\
\text { Graduates with abilities that include; } \\
\text {-Critical thinking (creative and } \\
\text { problem solving) }\end{array}$ \\
-Decision making (formative and \\
summative) \\
- Creativity, innovation and \\
entrepreneurship \\
-Communication, collaborations and \\
linkages
\end{tabular}


Figure 2: Constructivist learner transformation process

Source: Authors (2012)

While Alfa et al (2011) model and study addressed the variables; this paper interrogates the assessment and the use of the likert scale in ascertaining that the graduates indeed possess the desired creative abilities which would show whether the transformation process is adequate or not. The Alfa et al (2011) did identify the factors that affect the output more than others and made suggestions on areas that need improvement.

\section{Methodology}

As is the gist of constructivism, experiential learning is important in that it lays emphasis on methods that people use that create meaning of the world through a series of individual constructs, a person's unique psychological processes or the filters that a person uses to place meaning over realities that transform order from chaos (Glasserfeld, 2010), in this paper we use a case study methodology. A case study methodology is an empirical enquiry that investigates a contemporary phenomenon within its real life context especially if the boundaries between the phenomenon and the context are not clearly evident (Yin, 2003). It is an in-depth study of a single unit, such as one individual, one group one organization or one program and so on (Ary, Jacobs \& Razarich, 2002. In his classic book on case stud research, Yin (1994) argues that case research and survey methods are better suited than other techniques for analyzing contemporary events. Case research is superior to survey methods at answering the" whys" and "hows" because the case analysis can delve more deeply into motivations and actions than structured surveys. Econometric analysis of achieved data better answers the question "what happened?" than either" what is happening?" The case study approach has been applied to at least their different situations in the study. First, to explain the causal links in real - life interventions that are too complex for other research strategies. Second, to describe real life context in which an intervention has occurred or for illustrative purpose. Third, to explore those situations where a single set of outcomes is not clear (Yin, 1984).

In this case Alfa registered for Masters Degree in 2006 for a two year (4 semester) academic program that was supposed to span 2006/2007 and 2007/2008 academic years. In an ideal constructivist learning environment, he should have graduated at the end of the year 2008. In the year 2007 he presented a paper from the data extracted from his master's thesis in an international conference and in early 2008 submitted his complete thesis for the examination process to commence. In April 2012 he was called to make an oral presentation of the thesis to a school postgraduate panel commonly referred to as "defense". The outcome was that he revises the thesis and resubmits in a period between 6 and 9 months. The bone of contention was the use of a 7 point likert scale in measuring the variables as shown in figure 1 and also the use of such items as "I always have a constructive discontent, always see need for improvement and always propose new methods for improvement". The co-author in this paper was in the panel as a supervisor and hand firsthand experience in the handling of the 
student in the examination process. This has raised the questions that beg answers as to whether likert scale can and should be used to measure effectiveness of learning and creativity as well as whether the universities in sub-Saharan Africa have laid down the appropriate infrastructure and transformation processes that lead to graduates with creative abilities in a timely and reliable manner as expected by the community and society as conceptualized in figure 2. The case and experience will extend and apply to others, Alfa's class was 10 registered students in 2006, 2 have successfully completed their research projects and graduated, 2 are yet to present their research project proposals and the others are in various stages of their research project but none has as at November 2012 submitted a thesis for examination.

\section{Data analysis and presentation}

The main question in the study by Alfa was whether allocative efficiency in the use of factor inputs in an academic institution and transformative process lead to maximization of production of acceptable levels of technologically creative and productive abilities among graduates in Kenyan universities (Alfa et al, 2011). Indeed, Weisz (1999) had suggested that there is little correlation between academic achievement and levels generic skills and that employability is not related to academic ability. This line of thought only suggests that it is not enough for a leaner to graduate with a first class honors or any such accolades. A lot more is expected. To test this, the factor inputs were conceptualized and operationalized to include student's aptitude, faculty, programs, facilities and teaching methods while the output was graduates with creative abilities as shown in figure 1. A sample of 180 students was chosen using quota sampling and purposive stratified sampling in the respective schools (departments) as this process involved the selection of a particular sample on purpose, that is, those students who were undertaking special projects and who were in the last semester of their final year and who were expected to shortly join the labour market, in an effort to determine their creativity. Each school had its quota and random sampling was used pick respondents from each school. A seven (7) point Likert scale was designed for each of the variables (See appendix 1).

\section{Creative ability}

In order to get a composite score on creative ability and items were designed to test the perception of the respondents, and grouped into Knowledge on creativity, project identification and development process and benefits accruing from learning creativity. A measure of creativity was then aggregated from the individual respondent scores on the sub-variables Knowledge, projects, identification and benefits. The overall creativity measure was high with a mean of 111.9 out of a maximum possible score of 163 . A creativity index, a unitless measure of each students learnt creative ability was established by dividing the individual respondents score on creativity by the maximum possible score 163 to get an index that ranges from 0 to 1 . The creativity index had a mean of 0.69 which is significantly high than the half mark of 0.5 as shown by the one sample t- test as shown in table 1 . 
Table 1: A One Sample T-Test With a Test Statistic of 0.5

\begin{tabular}{|l|l|l|l|l|l|l|}
\hline & $\begin{array}{l}\text { Test Value } \\
=0.5\end{array}$ & & & & & \\
\hline & $\mathrm{t}$ & $\mathrm{df}$ & Sig. (2-tailed) & $\begin{array}{l}\text { Mean } \\
\text { Difference }\end{array}$ & $\begin{array}{l}95 \% \text { Confidence } \\
\text { Interval of the } \\
\text { Difference }\end{array}$ & \\
\hline & & & & & Lower & Upper \\
\hline $\begin{array}{l}\text { Creativity } \\
\text { index }\end{array}$ & 11.965 & 130 & .000 & .1867 & .1558 & .2176 \\
\hline
\end{tabular}

Source: Alfa et al (2011)

Since the $p=0.000$ is less than 0.05 , the alpha value, the null hypothesis that the mean is 0.5 is rejected and it is concluded that it is significantly high than 0.5. This suggests that the majority of the respondents have acquired significant levels of creativity in their respective training programs.

\section{Students Aptitude}

The variable student's aptitude was measured via questions and items on individual aptitude, learning of creativity through training and exposure, natural curiosity, ideas, proposals and problems, constructive discontent and problem solving approaches. Students were asked to assess themselves on items set out in appendix 1 on a lickert scale ranging from 1 to 7 . The items are known qualities and characteristics of creative individuals. The closer the score is to seven, the better the aptitude to learn creativity. The mean score on each item is significantly higher than 4. This shows a self- assessment that there is high aptitude in learning creativity. A score around 4 would indicate indecisiveness while scores significantly below 4 shows absence or lack of ability to learn creativity. To develop an individual total score on all items, the individual's responses were aggregated. The results show that the students mean aptitude 92.26 is significantly higher than the half mark of 63 indicating above average capability. An aptitude index is obtained by dividing the total scores by 126 the maximum possible score so as to reduce it to a continuum ranging between 0 and 1 . The mean aptitude index is 0.73 which is significantly higher than the midpoint 0.5 as shown by the one sample t test. Since the students aptitude is an input factor and hence an independent variable, a regression analysis shows that it is a predictor of creative abilities with $r$ (Karl Pearson's coefficient of correlation) value of 0.597 which indicates that there is a relationship that can be described as strong. The $\mathrm{r}$ square $\left(\mathrm{r}^{2}\right)$ value of 0.351 suggests that $35.1 \%$ of the change in the level of creativity can be explained by a unit change of the aptitude level.

\section{Faculty members/Lecturer's ability to teach creativity}


The variable Faculty, which sought to establish the faculty, teaching staff and/or lecturer's ability to teach or facilitate learning of creativity was synthesized from the qualification, and experience of staff, relationship between merit and promotion/rank of the faculty member, faculty's productivity in relation to titles, faculty's publications in refereed journals, faculties participation in consultancies and faculties participation in academic seminars, conferences and workshops. The students/respondents were asked to assess the attributes deemed essential for teaching creativity by lecturers. The items were all listed positively so that on the lickert scale the closer to 7 the better and indicates the respondent's perception of the lecturer's competence. The general response on all items is shown in appendix 1. On the whole, the student/respondents assess the competence/ability of the lecturer to teach creativity as below average with the mean score on main items below 4 indicating disagreement on the availability or possession of the attribute thought to aid teaching of creativity among lecturers. The few items whose mean is around 4 indicates indecisiveness or simply don't know. A faculty competence index was created by aggregating the individual respondent's scores on all the 17 items and then divided by 119 the total possible maximum score. The mean score of 63.24 is just about half of the total maximum score. This suggests that students see their lecturers to have average ability to teach creativity. An index of the faculty member's ability was developed by dividing each total score for the respondents by 119 to get an index lying between 0 and 1 . The mean index 0.531 is just above half mark. A one sample t test table 2 shows that it is not significantly higher than 0.5 as shown in table 2 .

Table 2: One-Sample t Test on the faculty members' ability index

\begin{tabular}{|l|l|l|l|l|l|l|}
\hline \multicolumn{7}{|l|}{ Test Value $=0.5$} \\
\hline & $\mathrm{t}$ & df & Sig. (2-tailed) & $\begin{array}{l}\text { Mean } \\
\text { Difference }\end{array}$ & $\begin{array}{l}\text { 95\% Confidence Interval of } \\
\text { the Difference }\end{array}$ & \\
\hline & & & & Lower & Upper \\
\hline $\begin{array}{l}\text { Faculty competence } \\
\text { index }\end{array}$ & 130 & .406 & $1.160 \mathrm{E}-02$ & $-1.5947 \mathrm{E}-02$ & $3.915 \mathrm{E}-02$ \\
\hline
\end{tabular}

Source: Alfa et al (2011)

Since $\mathrm{p}=0.406$ is higher than 0.05 the significance level, it is concluded that there is no sufficient evidence to show that the mean is not the same as 0.5. This indicates that the students assess their lecturer's ability to teach creativity as average, neither good nor poor. To test whether there is a relationship between creativity and faculty, a regression analysis was run whose results suggest a weak relationship. The Karl Pearson's product moment coefficient of correlation $r=0.197$ is low and suggests a weak relationship. The $r$ squares $\left(r^{2}\right)$ $=0.031$ indicates that only $3.1 \%$ of the change in level of creativity can be explained by a unit change in the level of faculty competence. The beta value $\beta=0.221$ is however significantly higher than 0 and hence the linear relationship holds with a model $\mathbf{C}=\mathbf{0 . 5 7 4}+$ 0.221L. This indicates that although the relationship is weak, the faculty factor cannot be ignored and should be actually strengthened to have greater influence on the student's creative ability. 


\section{Influence of teaching facilities on learning of creativity}

The facilities variable was synthesized from questions and items in the likert scale that included laboratories and workshops, supply of workshop and laboratory facilities, availability of space and student's enrolment, use of internet and library facilities and acquisition of new facilities for use by departments following introduction of self sponsored students. The respondents were asked to assess the learning/teaching facilities available to them on a scale of 1 to 7 . The responses on the various items indicating level of satisfaction on availability and access are as shown in appendix 1. The facilities were assessed to be inadequate in all spheres. It is noteworthy that the facility judged to be the poorest are the laboratory, materials and the library with a mean score of 2.8, 2.9 and 3.000 on a scale of 1 to 7 respectively yet they are the academics heart of creativity and existence. When all items are pooled together the student's score on facilities are a mean of 25.5 out of a possible total of 70 which is on the lower side. The total score on all items by a respondent were divided by 70 to get an index of facilities that range between 0 and 1 . A one sample $t$ test on calculated index of facilities shows that the mean, 0.364 is significantly less than half, 0.5. A linear regression analysis of the facility index and the creativity index indicates that the linear relationship between the variables is very weak $r=0.039$ with an $r$ squared $\left(\mathbf{r}^{2}\right)=-0.002$, indicating that the way things are, a change in teaching facilities explains a reduction of $0.2 \%$ of creative abilities for every unit of change.

\section{Contribution of the academic programs in learning creativity}

The academic programs implemented by the various academic institutions have an integral role to play in the process of developing students with creative abilities. This variable was assessed by questions and items in the likert scale on suitability of the academic programs and courses, program role in learning of skills, design of programs, program development, program review, university/industry link, practical projects, design of courses in programs, team work in program implementation, exhibitions and program and professional competence development. All items, appendix 1, were stated positively indicating desirability and that the higher the rating on the scale shows the respondents satisfaction on the program with regard to that item. All the respondents rating was aggregated to give the total score on the programs by each respondents and an index calculated by dividing the total score by 91 the maximum possible score on all items so that the index range from 0-1. Except the items on practical requirements, projects and competence outcome, where respondents are indecisive, all other items are rated lowly with a mean index of 0.549 which is significantly higher than 0.5 , the mid -point as shown in table 3. 
Table 3: One-Sample t-Test of the difference between the mean programs index

\begin{tabular}{|l|l|l|l|l|l|l|}
\hline \multicolumn{7}{|l|}{ Test Value $=0.5$} \\
\hline $\begin{array}{l}\text { Academic programs } \\
\text { adequacy for } \\
\text { creativity index }\end{array}$ & $\mathrm{t}$ & $\mathrm{df}$ & $\begin{array}{l}\text { Sig. } \\
(2 \text {-tailed } \\
\end{array}$ & $\begin{array}{l}\text { Mean } \\
\text { Difference }\end{array}$ & $\begin{array}{l}\text { 95\% Confidence Interval of } \\
\text { the Difference }\end{array}$ \\
\hline & & & & & Lower & Upper \\
\hline & 4.520 & 257 & .000 & $4.880 \mathrm{E}-02$ & $2.754 \mathrm{E}-02$ & $7.006 \mathrm{E}-02$ \\
\hline
\end{tabular}

Source: Alfa et al (2011)

This indicates that the students rate the programs to be good for capability to facilitate learning creativity. Regression analysis shows that the Karl Pearson's correlation coefficients $r=0.273$ is low while the $r$ square $\left(r^{2}\right)=0.075$ shows that only $7.5 \%$ of the change in creative abilities can be explained by a unit change in programs which is not good enough.

\section{The teaching methods and their influence on creativity learning at university level}

The measure of the variable on instructional methods used was constructed from questions and items on field and industrial visits, innovative teaching methods, use of instructional media, use of experiments in laboratories and academic/industry partnerships. The mean score on each item is shown in appendix 1 and indicates that except field and industrial visits, and practical and projects which have a score of more than 4 the mid mark, all other methods are rated poorly. When all items are pooled together, the total score for each item by the respondents is divided by 126 the maximum possible total score for all items to get a methodology index. The mean methodology index is 0.42 which is significantly lower than the midpoint 0.5 as shown by the one sample t test, $\mathrm{p}=0.000$ value which is less than 0.05 . A linear regression analysis shows that the relationship between the teaching methodology index and the creative abilities index is very weak with Karl Pearson's product moment coefficient of linear correlation $r=0.148$. The $r$ squared $\left(r^{2}\right)=0.018$ indicates that only $1.8 \%$ of the change in creativity can be explained by a unit change in methodology index. A test on the beta value -0.142 shows that it is significantly lower than zero and hence cannot be ignored but it is negative. The linear regression model

$\mathrm{C}=\alpha+\beta \mathrm{M}$, with $\alpha=0.752$ and $\beta=-0.142$, hence $\mathrm{C}=0.752-0.142 \mathrm{M}$

This sends a rather strong message that a lot need to be done on the teaching methodology because the model is simply suggesting that the student respondents see the methods used to kind of distract them and takes away their creative abilities. 


\section{Discussion of findings}

This study has established that the respondents acquired significant levels of creativity. This is encouraging considering that the respondents were finalists who were on their way to join the labour market. The creativity index with a mean of 0.69 on a scale of 0 to 1 is fairly good. Creativity is frequently associated with notions such as talent; spontaneity and coincidence, like; factors that cannot be influenced or determined but ultimately are left to chance. It is however notable that if the environment is conducive for learning, acquiring and/or developing creativity, the constructivist learning environment, it can be achieved. Landry (2000) note that the favorable conditions include team work, cross cultural exchange grounded in socio-cultural diversity, trans and inter-disciplinarily, time and resources and a risk-taking culture that tolerates and even encourages failure. Higher education institutions and their external stakeholders influence their level of creativity by enhancing these conditions through specific processes and structures at different levels and in different spheres. According to Gertler and Vinodrai, (2004), the key to creativity lies in a formula that includes the three T's: Technology, Talent and Tolerance. If this assumption is correct, then higher education institutions are central to a region's creative capital since they supply at least two (i.e. Talent and Tolerance) if not all three of the T's. The quality of higher education and creativity is affected by four (4) Cs forces: i) The changing University customs characteristics, ii) Increasing competition, iii) Rising costs, and iv) the impending crises all of which are challenges in Least Developed Countries (LDCs). Mpaata (2010) observed that to understand and manage these forces, institutions of higher education need to continuously improve and strengthen them or else they cease to be centers of academic excellence, hence the need to for continuous assessment of how they are performing in these fronts. However, measuring of creativity is what has been challenged orally, albeit with differing opinion. In this study, the measurement of creativity and other parameters and variables was based on social perception, which essentially, is that part of perception that allows people to understand the individuals and groups of their social world, and thus an element of social cognition. It allows people to determine how others affect their personal lives. While social perceptions can be flawed, they help people to form impressions of others by making the necessary information available to assess what people are like. Missing information is filled in by using an implicit personality theory: if a person is observed to have one particular trait, observers tend to assume that he or she has other traits related to this observed one. These assumptions help to "categorize" people and then infer additional facts and predict behavior. The use of the likert scale was therefore, supposed to assess this perception and the seven point scale deliberately designed to give measures that differentiate that perception resulting with measures of central tendency that coupled with a large sample size and many items for each variable, give a fairly good representation of the society's perception.

On students aptitude, the question is whether the students, one of the most important community, in an institution of higher learning has what it takes to learn, acquire, develop and use creativity in the work place. Gagné (1991) identifies four aptitude domains representing giftedness: intellectual, creative, socio-affective and sensor-motor; and as many fields of talent 
as there are fields of human activity; e.g., academics, trades and craft, technology, arts, social action, business, athletics and sports. Catalysts (positive or negative impact) for talent development include: motivation, temperament/personality and environmental factors (surroundings, persons, understanding, events). As expected, the student's aptitude is noted to be high with a mean aptitude index of 0.73 on a scale of $0-1$. Students entering the university have been screened and sifted through a rigorous examination process, exposure and experiences and are expected to exhibit and exploit certain talents and capabilities in problem solving in the society. The faculty, the other community and factor input in a university, are judged by the respondents to have average ability with a mean of 0.53 , which is not significantly higher than 0.5 the midpoint of a lickert scale. As noted by Bartel (2001), the teachers are often blamed for the diminished inclination by students to be creative as they (students) become more socialized and intelligent. Consequently, a question mark has been put here on the ability of the faculty in universities in LDCs to facilitate learning/acquiring of creative abilities.

The facilities were adjudged to be poor and inadequate with a mean score of 0.364 on a continuum ranging from 0 to 1 . The programs, though faring better, were rated lowly at 0.549 on a $0-1$ scale. This puts to question the adequacy and appropriateness of the learning environment created in universities in LDCs. Undergraduate programs ad MBA programs have been criticized for stressing analytical and classification skills and lack focus on creativity (Karr, 2002; Gilbert et al (1996) noted that graduates are capable of performing break even and return on investment analysis (and other analysis) but lack capability in more subjective areas such as creativity. The teaching methods are rated poor with a mean index of 0.42 on a scale of 0 to 1 with a weak negative relationship between teaching methods and creativity which is seen as distracting the respondents and learning of creativity at the university level. As in the case of faculty ability, doubt has been cast on effectiveness of the methods employed, and hence on the whole, the effectiveness of the learning environment. Obviously a facilitator/faulty is the key to effective teaching and learning. Clarke (1989) notes that an experienced facilitator's/faculty's knowledge and skill regarding methods of instruction may be compared to a maintenance technician's toolbox. The facilitator's tools are teaching methods. Clarke (1989) avers that just as the technician uses some tools more than others; the instructor will use some methods more often than others. As is the case with the technician, there will be times when a less used tool will be the exact tool needed for a particular situation. The facilitator's success is determined to a large degree by the ability to organize materials and to select and utilize a teaching method appropriate to a particular lesson.

The findings above suggest all is not well in the teaching/learning of creativity. Looking at the transformation process (the constructivists learning activities) figure 2, it is not clear how effective the interactive and experiential the learning involved is and also the extent to which modelling, coaching and scaffolding is used facilitated by a clear functional constructivists learning environment. Babalola (2007) observes that research evidence and comments from the public indicts the universities for not fulfilling her mandate of producing quality graduates but are rather churning out half-baked, ill-equipped graduates who cannot meet the expectations of 
society. Commenting on the gap between expected and actual skills acquired, Kerre (2000) opined that lack of qualified teachers and instructors has contributed to the growing gap between technical training and the world of work (Kerre, 2000).

In this case, Alfa's case casts doubt. Modeling, Mentoring and coaching are processes that enable individuals and participants to achieve their full potential as mentors offers ongoing support and development opportunities to the mentee (Clutterbuck 2004). Scaffolds may be tools, such as cue cards, analogies, and models; or techniques, such as teacher modeling, prompting, or thinking aloud. The term "scaffolding" refers to the support that a teacher can give learners so that they can work at a much higher level than is possible on their own. Are university faculty members playing these roles? The postgraduate program has taken Alfa more than 6 years to accomplish with handles being placed even after thesis examination. The bone of contention during the oral presentation was the use of the seven (7) point scale with one panellist who happens to be the one in charge of post graduate programs in the school obstinately insisting that likert scales are only 5 points and nothing more, nothing less. Ironically the three (3) thesis examiners, 2 of who were in the oral presentation panel had scored the thesis 72,69 and 60 on a scale of 0 to 100 averaging $67 \%$. The oral presentation was scored on average 11.4 on a scale of 0 to 20 . The other contradiction was in the examiners comments. One stated, "The thesis reflects a well researched topic and indicates some level of originality by the candidate - the score 72 out of 100 ". The second, "Overall, the thesis is well structured in a logical manner and shows awareness of the requirements for a master's degree study - 60 marks. Lastly, the thesis is adequate in form and content, has made contribution to knowledge and reflects adequate understanding of the subject. The contradiction? The panel goes ahead to bar the candidate from making corrections, finalize and submit the thesis in less than six months and not later than 9 months. The magnitude of what was wrong is not reflected either in the examiners comments nor the panels scores of over $50 \%$ indicating that there is still a problem of subjectivity negativity the role of facilitators in constructionist's activities of modelling, coaching and scaffolding. The very presence $f$ an item in the likert scale questions on "Constructive discontent" irked one of the panellists arguing that a respondent cannot be asked such question. Looking at the context and the type of respondents, undergraduates doing their final semester after which they join the labour market, would simply portray a calibre of faculty that is not ready for teaching/learning in a constructivist's environment.

\section{Conclusion and way forward}

The study has established that efforts have been made to create a constructivist learning environment the university with students having a good level of aptitude, facilities and faculty rated lowly and the programs fairly well viewed by the students. It does however; suggest that a lot need to be done to tap the three Ts of Technology, Talent and Tolerance in a free and democratic environment. The learning activities need to be anchored in teaching methods that emphasize interactive and experiential learning addressing the needs and goals of the society. The faculty whose competence and exposition has been put to question need not only play the 


\section{Macrothink}

Journal of Sociological Research

ISSN 1948-5468

2013, Vol. 4, No. 1

roles of models, coaches, mentors and scaffolds but also engage students gainfully in problem based learning. There are a variety of tools that can be used to assess effectiveness in teaching/learning creativity and the likert scale will do as long as it clearly captures the context and the items are designed to capture the parameters and variables it purports to measure. The quantitative data has been obtained from a large sample size; there can be no limit to the creative use the data can be put to. Finally, it is recommended that the universities look at the learning environment with a few to improving some of the factor inputs, learning activities and the rate of through put in the system especially for the postgraduate students. 
References

Alfa; Ng'ang'a, S.I. and Ondieki, M. (2011). Nurturing Technological Creativity and Innovativeness: The Ultimate Challenge for the Universities and Technical/Vocational Institutions in Kenya. Journal of Kenya Institute of Management ISSN 2074-4730 Vol. 3 Pg 182-189. Nairobi: Kenya Institute of Management

Amabile, T. M. (1996). Creativity in context: Update to "The Social Psychology of Creativity." Boulder, CO:Westview Press.

Bartel, Marvin (2001). Teaching creativity. www:creativity teaching/F:/Teaching\% 20 creativity.htm Basic Education Project/ Department for International Development.

Brunner, J. (1986) Actual Minds Possible Words. Cambridge, Ma University Press>

Baer J. (2008). Commentary: divergent thinking tests have problems, but this is not the solution. Psychol. Aesthet. Creat. Arts 2:89-92

Babalola, J. B. (2007). Reinventing Nigerian higher education for youth employment in a competitive global economy. A retirement lecture in the University of Calabar, Calabar, Nigeria.

Clarke, D. F. (1989). Communicative theory and its influence on materials production. Language Teaching, 22, 73-86.

Csikszo-tmitialy, M. (1996). Creativity Flow and the poyology of discovery and inventions. New York; Harper Collins).

Cheung PC, Lau S, Chan DW,WuWYH. (2004). Creative potential of school children in Hong Kong: norms of theWallach-Kogan Creativity Tests and their implications. Creat. Res. J. 16:69-78

Clutterbuck, D. (2004). Everyone Needs a Mentor. London, Chartered Institute of Personnel and Development.

Dawes, John (2008). Do data characteristics change ccording to the number of scale points used? An experienced using s-point used? An experience using 5- points 7points and 10- points scales.

Donald B. and Manow, D. (2003). Competing for talent, Implication for social cultural policy in Canadian city- regions. A report prepared for strategic research and analysis. Ontario Canadian heritage, Ottawa

Epstein R, Schmidt SM,Warfel R. (2008). Measuring and training creativity competencies: validation of a new test. Creat. Res. J. 20:7-12

Fauconnier, G. and Turner, 19. (2002) The way we think conceptual blending and the minds hidden complexities. Basic books Student perception in developing a multimedia project within a constructive learning environment. A Malaysia Experience. Dr Mai NEO and Dr Tse-Kia-HEO

Glasersfeld, E.V (1996) aspects of radical constructivism. In M pakman (Ed), Consturctiones de la Experiment humana (23-49). Barcelona, Spain:

Gilbert, R.B., Fernandez, F.F. andHorsfield,D., (1996), Shear Strength of a Reinforced

Geosynthetic Clay Liner, Journal of Geotechnical Engineering, in press. 
Horn, D. and Salvendy, G. (2006). Consumer-based assessment of product creativity: A review and reappraisal. Human Factors and Ergonomics in Manufacturing \& Service Industries, 16, 155-175.

Gagné, F. (1991), Towards a Differentiated Model of Giftedness and Talent by, in Handbook of Gifted Education edited by N. Colangelo \& G. A. Davis.1974 7(2): $175-192$.

Gilbert, F.W., P.J. Prenshaw \& T.T. Ivy. (1996). A preliminary assessment of the effectiveness of creativity training in marketing. Journal of Marketing Education, 18(3), 46-56.

Jonassen, D. (1999). Designing constructivist learning environments. In C. Reigeluth (Ed.), Instructional design theories and models: A new paradigm of instructional KarlKapp (2010). Likert type scales: examples sampled and information Retrived http://astoreamoazon.com www.karlkapp.co.ke

Kalyar, M. N (-). Creativty, self- leardership and individual innovations. The journal of commerce ISSN: 2220-6043. Hailey College of commerce University of Punjab Pakistan>theory (Vol. II, pp. 215-239). Mahwah, NJ: Lawrence Erlbaum Associates.

Karr, S. S. (2002). Striving for excellence. Financial Executive, 18(2), 69-71.

Lee, J. H. M., Lee, F. L., \& Lau, T. S. (2008). Folklore-based learning on the web-pedagogy, case study, and evaluation. Journal of Educational Computing Research, 34(1), 1-27.

Laffey, Mark and Jutta Weldes (2008) Beyond Belief: Ideas and Symbolic

Technologies in the Study of International Relations, European Journal of International Relations 3(2): 193-237.

Likert, R (1993). A technique for the measurement of attitudes archives of psychology, No 140.

Mc Lead, S.A. (2008). Likert Scde. Retrieved from http://www.simplypsycology.org/Scde: httml 0n 11/11/2012

Mc lean L. D. (2005) Organizational cultures influences on creativity and innovation: a review of literature and implications for human resource Development advances in developing human resources 7(3), 226.

Mumford MD, Vessey WB, Barrett JD. (2008). Commentary.Measuring divergent thinking: Is there really one solution to the problem? Psychol. Aesthet. Creat. Arts 2:86-88

Mpaata A. K. (2010) University Competiveness through Quality assurance; The Challenging Battle for Intellectuals

Retrieved from; www.intconfhighered.org/FINAL\%20Sarah\%20Bunoti.pdf on; $11^{\text {th }}$

Nov 2012

Nassif C, Quevillon R. (2008). The development of a preliminary creativity scale for the MMPI-2: the C scale. Creat. Res. J. 20:13-20

Okwakol M.J.N. (2009) The Need for Transformative Strategic Planning in Universities in Uganda. NCHE Journal Kampala.

Retrieved from; www.intconfhighered.org/FINAL\%20Sarah\%20Bunoti.pdf on; $11^{\text {th }}$

Nov 2012

Ramocki, S.P., (1996) Metacognition and Transfer: Keys to Improving Marketing 
Education. Journal of Marketing Education, 29(1), pp. 18-24.

Reiter-Palmon, R., Illies Young, M., Kobe, L., Buboltz, C. and Nimps, T. (2009). Creativity and domain specificity: The effect of task type of multiple indices on creative problem solving. Psychology of Aesthetics, Creativity, and the Arts, 3, 73-80.

Sternberg, R.J (Ed (1999). Hanseboxc of creativity, Cambridge, England: Cambridge

University press

Seldin, P o (1999). Current practices- Good Bad- Nationally. In Seldin P and associates (Eds), Changing practices in evaluating teaching: a Practical guide to 1 proved Faculty, performance and promotion tenure decisions (PP1-24)

Simonton, D. K. (2009).Varieties of (scientific) creativity: A hierarchical model of disposition, development, and achievement. Perspectives on Psychological Science, 4, 441-452.

Silvia PJ, Winterstein BP, Willse JT, Barona CM, Cram JT, et al. (2008). Assessing creativity with divergent thinking tasks: exploring the reliability and validity of new $\quad$ subjective scoring methods. Psychol. Aesthet.Creat. Arts 2:68-85

Sternberg, J. Robert and Swerling-Spear, Louise (1999). Perspectives on Learning Disabilities: Biological, Cognitive, Contextual. Colorado: Westview Press.

Tepper, A. B. (1999). A journey through geometry: Designing a city park. Teaching Children Mathematics, 5(6), 348-352.

Wellestrand $\mathrm{Ai}$ and Tjeldvoll, A. (2003). Creativity curricular and paradigms. Scandiviaian Journal of Educational research, 47(3), 359-372.

Yin, R. K. (2003). Case study research: Design and methods (3rd ed.). Thousand Oaks, CA: Sage.

Yin, R.. K. (1984). Case study research: Design and methods. Beverly Hills, CA: Sage. Yin, R. K. (1994). Case study research: Design and methods (2nd ed.). Thousand Oaks, CA:Sage. 
Appendix 1 A: Mean Analysis of the variables

Indicators of creative ability

\begin{tabular}{|c|c|c|c|c|c|}
\hline Knowledge on creativity & $\mathbf{N}$ & Min & Max & Mean & $\begin{array}{l}\text { Std. } \\
\text { Deviation }\end{array}$ \\
\hline $\begin{array}{l}\text { Creativity starts with knowledge accumulation, } \\
\text { reading, conversation, experience and learning }\end{array}$ & 127 & 1 & 7 & 5.02 & 1.86 \\
\hline $\begin{array}{l}\text { Knowledge accumulation is followed by } \\
\text { incubation, during which period , one } \\
\text { subconsciously mulls over information }\end{array}$ & 128 & 1 & 7 & 4.70 & 1.64 \\
\hline $\begin{array}{l}\text { Incubation is followed by idea experience, where } \\
\text { an innovative or novel idea emerge or is discussed }\end{array}$ & 128 & 1 & 7 & 4.82 & 1.68 \\
\hline $\begin{array}{l}\text { The new idea is then evaluated, decision put to } \\
\text { hold, till more information is obtained an idea } \\
\text { crystallized }\end{array}$ & 126 & 1 & 7 & 8.22 & 1.69 \\
\hline $\begin{array}{l}\text { Finally the idea is implemented after deep } \\
\text { understanding and insight, idea fleshed out and } \\
\text { business plan or working drawings developed }\end{array}$ & 126 & 1 & 7 & 5.22 & 1.69 \\
\hline \multicolumn{6}{|l|}{ Project identification method } \\
\hline $\begin{array}{l}\text { Incremental improvement of past student special } \\
\text { project(evaluation) }\end{array}$ & 116 & 1 & 2 & 1.60 & .49 \\
\hline $\begin{array}{l}\text { Combined two or more existing projects ideas to } \\
\text { form a new project (Synthesis) }\end{array}$ & 114 & 1 & 3 & 1.52 & .52 \\
\hline Used old technology in a new way & 115 & 1.00 & 2.00 & 1.4348 & .4979 \\
\hline $\begin{array}{l}\text { I shifted attention from the expected, normal and } \\
\text { routine to look at the problem from a different } \\
\text { angle }\end{array}$ & 118 & 1.00 & 2.00 & 1.4237 & .4963 \\
\hline $\begin{array}{l}\text { Discussions with other students, lecturers, } \\
\text { technical staff }\end{array}$ & 116 & 1.00 & 2.00 & 1.2759 & .4489 \\
\hline PROJECT identification method & 129 & .00 & 6.00 & 2.9535 & 1.3799 \\
\hline \multicolumn{6}{|l|}{ Benefits accruing from learning creativity } \\
\hline Satisfied requirement forward of degree & 121 & 1.00 & 7.00 & 5.7521 & 1.4100 \\
\hline $\begin{array}{l}\text { Developed creative abilities that can always be } \\
\text { applied in the place of work }\end{array}$ & 122 & 2.00 & 7.00 & 5.6967 & 1.3167 \\
\hline $\begin{array}{l}\text { Came up with physical project that will develop } \\
\text { further and commercialize }\end{array}$ & 119 & 1.00 & 7.00 & 4.7143 & 1.6982 \\
\hline $\begin{array}{l}\text { I am able to solve a specific community problem } \\
\text { and satisfy a need in the market }\end{array}$ & 123 & 1.00 & 7.00 & 5.3008 & 1.5037 \\
\hline $\begin{array}{l}\text { I develop a strong sense of and ability to work in } \\
\text { teams }\end{array}$ & 122 & 1.00 & 7.00 & 5.1066 & 1.6852 \\
\hline Acquired an expanded sense of time i feel i have & 122 & 1.00 & 7.00 & 4.9426 & 1.5228 \\
\hline
\end{tabular}




\begin{tabular}{|l|l|l|l|l|l|}
\hline enough time to pursue creative work & & & & & \\
\hline $\begin{array}{l}\text { Acquired or developed a sense of freedom. i feel } \\
\text { free and charged to seek to know and develop new }\end{array}$ & 119 & 1.00 & 7.00 & 5.2101 & 1.6564 \\
\hline $\begin{array}{l}\text { Project have made me value relationships and feel } \\
\text { better about others }\end{array}$ & 124 & 1.00 & 7.00 & 5.2581 & 1.5611 \\
\hline $\begin{array}{l}\text { Project work and creativity ability will prevent } \\
\text { impulse and idle time }\end{array}$ & 120 & 1.00 & 7.00 & 4.8000 & 1.7277 \\
\hline $\begin{array}{l}\text { Learning creativity and ability to complete } \\
\text { functional projects }\end{array}$ & 124 & 1.00 & 7.00 & 5.1855 & 1.4106 \\
\hline $\begin{array}{l}\text { I feel a strong sense of connection to others who } \\
\text { have succeeded }\end{array}$ & 122 & 2.00 & 7.00 & 5.3443 & 1.3408 \\
\hline I have learnt to have faith and confidence & 124 & 1.00 & 7.00 & 4.9597 & 1.5845 \\
\hline $\begin{array}{l}\text { I have learnt to appreciate, respect and honor the } \\
\text { gift of creative inspiration }\end{array}$ & 122 & 1.00 & 7.00 & 5.4344 & 1.4826 \\
\hline I've learnt to acknowledge my creative ability & 122 & 2.00 & 7.00 & 5.6230 & 1.3132 \\
\hline $\begin{array}{l}\text { I feel adequately prepared for a creative role in the } \\
\text { world of work }\end{array}$ & 119 & 1.00 & 7.00 & 70.7899 & 712.4153 \\
\hline $\begin{array}{l}\text { Hive solutions and technologies to develop } \\
\text { innovative solutions and technologies }\end{array}$ & 123 & 2.00 & 7.00 & 5.6504 & 1.3670 \\
\hline Benefits accruing from learning creativity & 131 & .00 & 110.00 & 78.5191 & 23.4204 \\
\hline Students creative ability & $\mathbf{1 3 1}$ & .00 & 153.00 & 111.9237 & 29.0147 \\
\hline Valid N (listwise) & & & \\
\hline
\end{tabular}

\section{Creative aptitude indicators}

\begin{tabular}{|l|l|l|l|l|l|}
\hline Attributes indlicative of ability to learn creativity & N & Min & Max & Mean & $\begin{array}{l}\text { Std. } \\
\text { Deviation }\end{array}$ \\
\hline To be creative, i have inherited natural talents & 128 & 1 & 7 & 4.1641 & 1.7693 \\
\hline I can learn creativity through training and exposure & 126 & 1 & 7 & 5.2857 & 1.5171 \\
\hline Normally and naturally curious & 123 & 1 & 7 & 5.5447 & 1.4613 \\
\hline $\begin{array}{l}\text { I always try to identify and challenge assumptions } \\
\text { behind ideas, proposals problems before accepting } \\
\text { them }\end{array}$ & 127 & 1 & 7 & 5.2598 & 1.4541 \\
\hline $\begin{array}{l}\text { always have a constructive discontent, see need for } \\
\text { improvement and propose new methods for } \\
\text { improvement }\end{array}$ & 127 & 1 & 7 & 5.1575 & 1.4443 \\
\hline $\begin{array}{l}\text { I enjoy challenges and willing to test my abilities to } \\
\text { the limit }\end{array}$ & 127 & 1 & 7 & 5.5197 & 1.5058 \\
\hline $\begin{array}{l}\text { I believe most problems can be solved, something } \\
\text { can be done to eliminate or alleviate almost } \\
\text { everything }\end{array}$ & 126 & 1 & 7 & 5.5794 & 1.6606 \\
\hline
\end{tabular}




\begin{tabular}{|l|l|l|l|l|l|}
\hline $\begin{array}{l}\text { I have commitment time and energy to address and } \\
\text { try to solve every problem }\end{array}$ & 128 & 1 & 7 & 4.9688 & 1.5417 \\
\hline $\begin{array}{l}\text { I have ability to suspend judgment and criticism } \\
\text { until Ii understand the other persons point }\end{array}$ & 126 & 1 & 7 & 4.9524 & 1.7383 \\
\hline I have optimistic attitude towards idea in general & 127 & 1 & 7 & 5.1024 & 1.6224 \\
\hline I always try to see good in the bad. & 126 & 1 & 7 & 4.9127 & 1.7019 \\
\hline $\begin{array}{l}\text { I do not mind problems or difficulties, they lead to } \\
\text { improvement }\end{array}$ & 121 & 1 & 7 & 5.3306 & 1.6196 \\
\hline $\begin{array}{l}\text { Unexpected and unwanted problems are not } \\
\text { necessarily bad they permit solutions }\end{array}$ & 127 & 1 & 7 & 5.1969 & 1.6136 \\
\hline $\begin{array}{l}\text { Preconceived based on experiences prevents me } \\
\text { from seeing beyond the known }\end{array}$ & 125 & 1 & 7 & 4.208 & 2.0052 \\
\hline $\begin{array}{l}\text { I always try to see things for what they can do not } \\
\text { what they are }\end{array}$ & 124 & 1 & 7 & 5.0565 & 1.5993 \\
\hline $\begin{array}{l}\text { I always try to avoid feelings that i do no tknow } \\
\text { what they are }\end{array}$ & 127 & 1 & 7 & 5.126 & 1.6714 \\
\hline I avoid thinking small and limiting myself & 126 & 1 & 7 & 5.4206 & 1.6265 \\
\hline $\begin{array}{l}\text { I avoid psychological blocks-refusing to do } \\
\text { something }\end{array}$ & 128 & 1 & 7 & 5.4766 & 1.6069 \\
\hline Total & & & & 92.2624 & \\
\hline
\end{tabular}

The maximum possible score on these items is 126 
Indicators of faculty members competence in teaching creativity

\begin{tabular}{|c|c|c|c|c|c|}
\hline $\begin{array}{l}\text { Indicators of faculty members competence in } \\
\text { teaching creativity }\end{array}$ & $\mathbf{N}$ & Min & Max & Mean & $\begin{array}{l}\text { Std. } \\
\text { Deviation }\end{array}$ \\
\hline $\begin{array}{l}\text { Most faculty in my department are highly qualified } \\
\text { and experienced }\end{array}$ & 128 & 1.00 & 7.00 & 4.6094 & 1.6801 \\
\hline Faculty merit bear a strong correlation to position & 126 & 1.00 & 7.00 & 4.3730 & 1.6911 \\
\hline $\begin{array}{l}\text { Faculty with high titles and position are equally } \\
\text { productive and contribute more to learning }\end{array}$ & 126 & 1.00 & 7.00 & 3.7381 & 1.6742 \\
\hline Most faculties have written articles & 128 & 1.00 & 7.00 & 3.6484 & 1.6581 \\
\hline $\begin{array}{l}\text { Most faculties are engaged in consultancy activities } \\
\text { that uses academic knowledge }\end{array}$ & 126 & 1.00 & 7.00 & 3.9206 & 1.6327 \\
\hline $\begin{array}{l}\text { Most faculties attend and present papers in } \\
\text { seminars, conferences and workshops }\end{array}$ & 127 & 1.00 & 7.00 & 4.2047 & 1.7698 \\
\hline $\begin{array}{l}\text { Faculty access good facilities to enhance their } \\
\text { academic abilities }\end{array}$ & 127 & 1.00 & 7.00 & 3.7480 & 1.8643 \\
\hline $\begin{array}{l}\text { FACULTIES have secretarial support provided to } \\
\text { facilitate processing academic documents hence } \\
\text { spending more time on research and creative work }\end{array}$ & 127 & 1.00 & 7.00 & 3.5591 & 1.6166 \\
\hline $\begin{array}{l}\text { Faculty access grant money for business, research } \\
\text { and hiring research assistant }\end{array}$ & 123 & 1.00 & 7.00 & 3.3252 & 1.7718 \\
\hline $\begin{array}{l}\text { Are involved in hiring of their colleagues so as to get } \\
\text { teams that work together and stimulate each other }\end{array}$ & 124 & 1.00 & 7.00 & 3.5887 & 1.6479 \\
\hline $\begin{array}{l}\text { Most have security of tenure hence can express } \\
\text { themselves freely }\end{array}$ & 125 & 1.00 & 7.00 & 3.6880 & 1.6820 \\
\hline $\begin{array}{l}\text { Encourages graduate students to work with them in } \\
\text { joint projects and publish papers jointly }\end{array}$ & 125 & 1.00 & 7.00 & 3.1520 & 1.7600 \\
\hline $\begin{array}{l}\text { uses creative teaching methods, employing new } \\
\text { methods to teach old course }\end{array}$ & 123 & 1.00 & 7.00 & 3.3171 & 1.7894 \\
\hline $\begin{array}{l}\text { Presents new creative ideas in class and encourage } \\
\text { obtaining feedbacks from undergraduates and } \\
\text { graduate students }\end{array}$ & 126 & 1.00 & 7.00 & 3.3730 & 1.7239 \\
\hline $\begin{array}{l}\text { Members are there and hold position on merit and } \\
\text { have contributed greatly in my learning throughout } \\
\text { my stay }\end{array}$ & 127 & 1.00 & 7.00 & 3.9055 & 1.7658 \\
\hline $\begin{array}{l}\text { Members are not overloaded hence have enough } \\
\text { time for research }\end{array}$ & 127 & 1.00 & 7.00 & 3.8740 & 1.9107 \\
\hline $\begin{array}{l}\text { Students ratio is good allowing direct contact and } \\
\text { learning }\end{array}$ & 127 & 1.00 & 7.00 & 3.2205 & 1.9062 \\
\hline
\end{tabular}




\section{Macrothink \\ Institute ${ }^{\mathrm{TM}}$}

Valid N (listwise)
Journal of Sociological Research ISSN 1948-5468 2013, Vol. 4, No. 1 
Indicators of availability, adequacy and access of facilities for teaching/learning creativity

\begin{tabular}{|l|l|l|l|l|l|}
\hline $\begin{array}{l}\text { Indicators of availability, adequacy and access of } \\
\text { facilities for teaching/learning creativity }\end{array}$ & Min & Max & Mean & $\begin{array}{l}\text { Std. } \\
\text { Deviation }\end{array}$ \\
\hline $\begin{array}{l}\text { Enough lab, workshops facilities for practical } \\
\text { sessions }\end{array}$ & 128 & 1.00 & 7.00 & 2.9141 & 1.8230 \\
\hline $\begin{array}{l}\text { Students access the facilities as frequently as need } \\
\text { rise }\end{array}$ & 123 & 1.00 & 7.00 & 3.1626 & 1.8659 \\
\hline $\begin{array}{l}\text { Adequate supply of tools, equipments and materials } \\
\text { need in teaching }\end{array}$ & 127 & 1.00 & 7.00 & 2.8740 & 1.6183 \\
\hline $\begin{array}{l}\text { Spaces are adequate for the students occupying } \\
\text { them at a time. ration is good }\end{array}$ & 127 & 1.00 & 7.00 & 3.2520 & 1.8169 \\
\hline The library is adequate and well resourced & 123 & 1.00 & 7.00 & 3.0000 & 1.8062 \\
\hline $\begin{array}{l}\text { Students access current books, journal magazines in } \\
\text { the library in acceptable time, to gather a wide } \\
\text { variety of emerging issues }\end{array}$ & 128 & 1.00 & 7.00 & 3.3203 & 1.9070 \\
\hline $\begin{array}{l}\text { Continuously have adequate information from both } \\
\text { electronic and print media in the library or students } \\
\text { hall on current challenges affecting society which } \\
\text { appeals to their creative abilities }\end{array}$ & 128 & 1.00 & 7.00 & 3.3750 & 1.8949 \\
\hline $\begin{array}{l}\text { Students easily access internet as a source of current } \\
\text { information and creative ideas }\end{array}$ & 125 & 1.00 & 7.00 & 3.6480 & 1.9187 \\
\hline $\begin{array}{l}\text { Recreation facilities are good and adequate to } \\
\text { facilitate stress free mind }\end{array}$ & 128 & 1.00 & 7.00 & 3.7422 & 1.9970 \\
\hline $\begin{array}{l}\text { Department continuously acquires new facilities to } \\
\text { accommodate changes in technology }\end{array}$ & 128 & 1.00 & 7.00 & 3.1172 & 2.0298 \\
\hline Valid N (listwise) & 116 & & & & \\
\hline
\end{tabular}


Indicators of respondents level of satisfaction with academic programs

\begin{tabular}{|c|c|c|c|c|c|}
\hline $\begin{array}{l}\text { Indicators of respondents level of satisfaction } \\
\text { with academic programs }\end{array}$ & $\mathrm{N}$ & Min & Max & Mean & $\begin{array}{l}\text { Std. } \\
\text { Deviation }\end{array}$ \\
\hline $\begin{array}{l}\text { Programmes an all courses in the program are } \\
\text { very good and well suited in developing } \\
\text { creative graduates }\end{array}$ & 128 & 1.00 & 7.00 & 3.5391 & 1.6832 \\
\hline $\begin{array}{l}\text { Program facilitates theory and practical } \\
\text { learning of skills that meets the needs and } \\
\text { challenges of the current world }\end{array}$ & 128 & 1.00 & 7.00 & 3.7812 & 1.6214 \\
\hline $\begin{array}{l}\text { Programmes are regularly reviewed to reflect } \\
\text { the changes in technology and the community } \\
\text { needs }\end{array}$ & 128 & 1.00 & 7.00 & 3.0234 & 1.6905 \\
\hline $\begin{array}{l}\text { Programmes support and encourage a strong } \\
\text { university/ industry link }\end{array}$ & 128 & 1.00 & 7.00 & 3.8594 & 1.8000 \\
\hline $\begin{array}{l}\text { Designed to encourage and support learners } \\
\text { centered approach to teaching and learning }\end{array}$ & 128 & 1.00 & 7.00 & 3.7402 & 1.7007 \\
\hline $\begin{array}{l}\text { Have adequate and require students to } \\
\text { undertake practical, projects and industrial } \\
\text { attachment to enhance learning by doing }\end{array}$ & 128 & 1.00 & 7.00 & 4.7244 & 1.6888 \\
\hline $\begin{array}{l}\text { Developed by the faculty members with the } \\
\text { collaboration of industry players and other } \\
\text { stakeholders to reflect the needs of the society }\end{array}$ & 128 & 1.00 & 7.00 & 3.8516 & 1.775 \\
\hline $\begin{array}{l}\text { Design of all courses i the program are market } \\
\text { driven emphasizing learning of creativity } \\
\text { through problem solving as opposed to } \\
\text { traditional course that emphasizes skills } \\
\text { development }\end{array}$ & 128 & 1.00 & 7.00 & 3.5714 & 1.7225 \\
\hline $\begin{array}{l}\text { Research and creative assignments are } \\
\text { integral components of all courses in the } \\
\text { programmes in the department }\end{array}$ & 128 & 1.00 & 7.00 & 3.4766 & 1.6118 \\
\hline $\begin{array}{l}\text { Group projects are inherent in the } \\
\text { programme to enhance student creative and } \\
\text { innovative ability through problem solving } \\
\text { and team work }\end{array}$ & 128 & 1.00 & 7.00 & 4.0157 & 1.7502 \\
\hline $\begin{array}{l}\text { The programmes encourages invention and } \\
\text { innovation by emphasizing techniques for } \\
\text { generating creative ideas }\end{array}$ & 128 & 1.00 & 7.00 & 3.6250 & 1.7614 \\
\hline $\begin{array}{l}\text { The programs facilities provide avenues and } \\
\text { opportunities for exhibiting creative works } \\
\text { and creativity and rewards the best and links } \\
\text { potential inventers to organizations and } \\
\text { bodies that assisting the commercialization of }\end{array}$ & 128 & 1.00 & 7.00 & 3.7638 & 4.9013 \\
\hline
\end{tabular}




\begin{tabular}{|l|l|l|l|l|l|}
\hline viable ideas & & & & & \\
\hline $\begin{array}{l}\text { Leads to the development of professional } \\
\text { competencies, confident and creative } \\
\text { graduates who are able to fit in any work } \\
\text { environment exploiting creative abilities and } \\
\text { face current and emerging challenges }\end{array}$ & 1.00 & 7.00 & 4.0625 & 1.7468 \\
\hline Valid N (listwise) & 123 & & & & \\
\hline
\end{tabular}




\section{Indicators of acceptability of teaching methods used to enhance teaching/learning} creativity

\begin{tabular}{|c|c|c|c|c|c|}
\hline $\begin{array}{l}\text { Indicators of acceptability of teaching methods } \\
\text { used to enhance teaching/learning creativity }\end{array}$ & $\mathbf{N}$ & Min & Max & Mean & $\begin{array}{l}\text { Std. } \\
\text { Deviation }\end{array}$ \\
\hline $\begin{array}{l}\text { Most common used method in my department } \\
\text { adequately enhances learning creativity }\end{array}$ & 123 & 1.00 & 7.00 & 3.4228 & 1.6297 \\
\hline $\begin{array}{l}\text { Teaching methods used allow adequate teacher } \\
\text { /student contact }\end{array}$ & 124 & 1.00 & 7.00 & 3.4839 & 1.5900 \\
\hline $\begin{array}{l}\text { Student centered teaching approaches are used } \\
\text { when and where approximate to exploit } \\
\text { individual learning capabilities }\end{array}$ & 125 & 1.00 & 7.00 & 3.6320 & 1.6091 \\
\hline $\begin{array}{l}\text { Because of the teaching methods used, students } \\
\text { easily learn, hence understand the activity and } \\
\text { the process }\end{array}$ & 123 & 1.00 & 7.00 & 3.2439 & 1.5276 \\
\hline $\begin{array}{l}\text { Members often use instructional media in } \\
\text { developing and teaching new concepts }\end{array}$ & 123 & 1.00 & 7.00 & 3.3740 & 1.5961 \\
\hline $\begin{array}{l}\text { The overhead projector is a commonly used } \\
\text { instructional media }\end{array}$ & 123 & 1.00 & 7.00 & 2.9106 & 1.8861 \\
\hline $\begin{array}{l}\text { PowerPoint projector is a commonly used } \\
\text { instructional media in the department }\end{array}$ & 124 & 1.00 & 7.00 & 3.3629 & 2.0888 \\
\hline $\begin{array}{l}\begin{array}{l}\text { Demonstrations are common in lesson } \\
\text { development }\end{array} \\
\end{array}$ & 121 & 1.00 & 7.00 & 3.1818 & 1.8886 \\
\hline $\begin{array}{l}\text { Laboratory experiments are commonly } \\
\text { undertaken to develop new concepts }\end{array}$ & 123 & 1.00 & 7.00 & 3.5772 & 1.7274 \\
\hline $\begin{array}{l}\text { Students practical and projects are carried out in } \\
\text { most courses frequently }\end{array}$ & 123 & 1.00 & 7.00 & 4.3496 & 4.1231 \\
\hline $\begin{array}{l}\text { Map wall charts graphs and } 3 \text { dimensional } \\
\text { objects are used to clarify issues when teaching }\end{array}$ & 127 & 1.00 & 7.00 & 2.9921 & 1.8279 \\
\hline $\begin{array}{l}\text { Computer simulation are used to demonstrate } \\
\text { relationships observed in real life }\end{array}$ & 123 & 1.00 & 7.00 & 3.1138 & 1.7704 \\
\hline $\begin{array}{l}\text { Videos, TV programmers and other electronic } \\
\text { media is used in class or lecture halls }\end{array}$ & 127 & 1.00 & 7.00 & 2.6142 & 1.8216 \\
\hline $\begin{array}{l}\text { Modern technology is adequately embodied in } \\
\text { the teaching methods }\end{array}$ & 123 & 1.00 & 7.00 & 2.9512 & 1.7266 \\
\hline $\begin{array}{l}\text { An academic industry partnership in teaching } \\
\text { the department where part time faculty members } \\
\text { are resourced from the industry or come in as } \\
\text { guest speakers }\end{array}$ & 127 & 1.00 & 7.00 & 3.4252 & 1.8836 \\
\hline $\begin{array}{l}\text { Imitation of success cases and novel projects is } \\
\text { used in to department to enhance learning }\end{array}$ & 126 & 1.00 & 7.00 & 3.2937 & 1.6689 \\
\hline Reverse engineering is encouraged and used in & 127 & 1.00 & 7.00 & 2.9449 & 1.7697 \\
\hline
\end{tabular}




\begin{tabular}{|l|l|l|l|l|l|}
\hline the department & & & & & \\
\hline $\begin{array}{l}\text { Field and industrial visits are used in the } \\
\text { department as a teaching approach }\end{array}$ & 127 & 1.00 & 7.00 & 4.7874 & 1.8967 \\
\hline Valid N (listwise) & 99 & & & & \\
\hline
\end{tabular}

